\title{
Tracing Accounting in Javanese Tradition
}

\author{
Ari Kamayanti a,1,*, Nurmala Ahmar ${ }^{\mathrm{b}, 2}$ \\ a State Polytechnic of Malang, Jl. Soekarno-Hatta 9, Malang, Indonesia \\ ${ }^{\text {b }}$ STIE Perbanas Surabaya, Jl. Nginden Semolo, Surabaya, Indonesia \\ ${ }^{1}$ arikamayanti@polinema.ac.id*; ${ }^{2}$ nurmala_amar@yahoo.com \\ * corresponding author
}

\section{ARTICLE INFO}

Article history

Received 27 January 2019

Revised 8 February 2019

Accepted 1 April 2019

Keywords

Slametan

Javenese

Social obligation

Mental recordings

Soul-spiritual gain

\begin{abstract}
Slametan as one of the Javanese ceremonies has been present ever since Islam arrived in Java and mingled with the previous religions such as Hindu and Buddha. Up to this day, slametan is still conducted and in the process there are social activities that involve the giving/receiving of goods and cash called buwuh or ndeleh. There are many varieties of slametan but this paper focuses on marriage and circumcision. This paper tries to explore the presence of accounting and its underlying values through a combination of two methods: hermeneutics and phenomenology. Hermeneutics involve interpretation of ancient texts that go back as far as $1030 \mathrm{AC}$, as well as interpretation of photographs. Phenomenology involves understanding experience and peeling off consciousness right down to metaphysical beliefs. To holistically understand accounting in Javanese and how it survives up to this day (its perseverance), a synchronic analysis is needed; i.e. combining interpretation of ancient texts and recent experiences. It is found that although physical recordings do exist, mental recordings are just as important. However, the values that are not left behind that might be the cause of accounting perseverance in slametan are cohesiveness /togetherness among the people, and spiritual as well as religious beliefs that would give rise to social obligations, mental recordings, and soulspiritual gain.
\end{abstract}

\section{Introduction}

In the globalization era, one might question the importance of exploring local needs and values through culture. The answer to that simple question lies in this proverb that is rooted from Javanese philosophy: "Budaya iku dadi kaca benggalaning bangsa". This means that a culture is a big mirror that reflects civilization of a nation [1]. Thus, an argument that could be proposed for the reason to conduct this research is to preserve a nation civilization because by following an international standard, local norms and culture would be eroded as globalization suggests a drive toward homogenization [2]. Globalization would result in cultural alienation or cultural 'cringe' i.e. losing a nation's identity.

Globalization originally springs from introducing a global market or international economic integration. Globalization is hence marked with trade agreements such as GATT ${ }^{1}$, NAFTA and

\footnotetext{
${ }^{1}$ GATT (General Agreement on Tariff and Trade) first signed in 1947, was designed to provide an international forum that encouraged free trade between members by regulating and reducing tariffs on traded goods and by providing mechanism for resolving trade disputes.
} 
AFTA. The keyword in all trade agreements is deregulation or removing trade barriers to reduce the scope of government [3]. Hence it is not exaggerating if it is believed that allowing the market mechanism to be sole director of the fate of human beings and their natural environment would result in demolition of society [4].

Globalization spreads its wings to accounting as International Financial Reporting Standards (IFRS) are implemented. Setting IFRS to the entire globe is an attempt to control accountancy 'software' by a few developed nations, in order to maintain their imperialism especially the US [5]. Lehman [6] delineated the accounting harmonization, as conception of liberal-accountability overlaps with free market reform, ignores difference and diversity. Globalization thus suppresses local accounting norms and supports the spirit of capitalism. The main enemy of the spirit of capitalism, in a life that demands ethical rules, is behavior and reaction types to the new situations. These behaviors and reactions are named: traditionalism [7].

Hence, it is as good as any time to reflect back to local values, and to preserve local heritage in order to reduce the adverse effect of globalization. One major culture in Indonesia is the Javanese. Since the arrival of Islam, the Javanese could be categorized into four groups: the Islamic Javanese that still holds the belief of Brahma and Buddha, the Islamic Javanese that believes in magic and dualism, the Islamic Javanese that believes in Animism, and the Islamic Javanese that holds pure Islam. The first three groups are called Kejawen [8]. These mixed beliefs are still dominant, hence regarded as the Javanese culture. One character that Kejawen has, is the ritual of Slametan that still exist up to this day.

Geertz [9] conducted a research in Pare, Java, during 1953-1959, managed to obtain the cost of rituals or ceremonials known as slametan. This, he claimed, was a difficult estimation of cost since “... people do not keep records of such expenditures". However this does not mean that there is no accounting found in slametan. It would be too fast to jump to such conclusion for he conducted the research during the years of low literary rate, and that accounting may be beyond simple bookkeeping for there is social obligation besides the recorded monetary values.

The research questions in this article are therefore: how does accounting form itself in the Javanese culture as reflected in slametan? How could this kind of accounting preserve itself in the midst of globalization? Hopefully, some values could be found that would help develop local accounting that would stand the destructive flow of globalization.

\section{Method}

Two qualitative methods are combined in this research to fulfill the need of obtaining answers to the research questions. The evidence of the presence of accounting must be explored in Javanese texts through Serat $^{2}$ and other forms of texts, including photographs. Some forms of written expenses as manuscripts are analyzed. This requires Hermeneutics. Hermeneutics provide answers through texts analysis. Burrell and Morgan [10] stated that the method of Hermeneutics involves human scientist adopting the style of literary analyst. In this research, texts that are analyzed range from as early as $1030 \mathrm{AC}$, and as late as the texts in well-known proverbs that still exist up to this day.

However, to get deep understanding or verstehen of the rich values in the text, the former analysis is not enough. Since slametan is still conducted nowadays, it is best to obtain the meaning of accounting by Phenomenology. Slametan is socio-activity that is rich with metaphysical beliefs. Phenomenology is the best method to use because it has epoche as one of its component to extract such belief. Phenomenology seeks to make explicit the implicit structures and meaning of human experiences [11]. It is the search for 'essences' that could not be revealed by ordinary observation or mere interpretation, such as done in Hermeneutics.

Phenomenology would require researcher to extract intentionality or consciousness, which is the correlation between the object as perceived (noema) and the subjective apprehension (noesis). Next, epoche must be conducted through what Husserl called "bracketing" metaphysical assumptions in order to get straight to the pure and encumbered vision of what a "thing" essentially is.

\footnotetext{
${ }^{2}$ Serat may contain prose of advice, as well as literatures that reflect philosophical way of life.
} 
Figure 1. Research Methods Framework

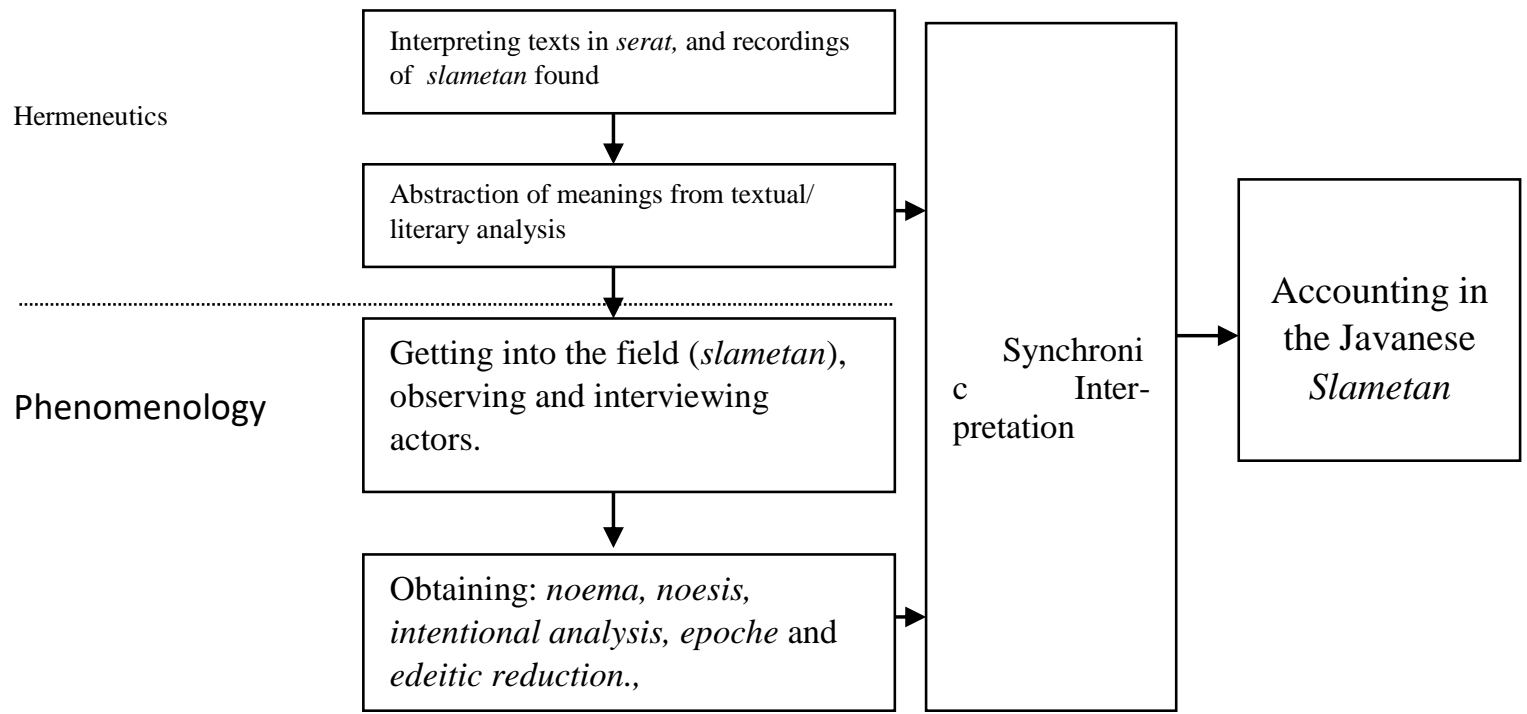

Finally, abstracting essences from consciousness or experiences are done by the researcher. This process is called Eidetic Reduction in Phenomenology. At this stage, interviews are carried out with informants who are still keeping recordings of Slametan: Tutik, Yani, Sudarmini, Sukijan, Siti Aminah, Mujiono, and Endah . Tutik (55 years old) is a labor in Sukodono. Yani (66 years old) is a regular a pensioner of school teacher. Sudarmini and Sukijan are married couple, 52 and 54 years old respectively, a teacher and an employee. Siti Aminah and Mujiono are also married couple in their mid 50s, a trader and a farmer. Endah is 45 years a shop owner at her house. Besides Tutik, all other informants are from Kediri, East Java. There are many kinds of slametan but in this research we limit them to circumcision and marriage. The interviews were conducted in separate sessions, each interview took 30 minutes to an hour. The research was done during August 2008- July 2009.

Then a complete interpretation of accounting in slametan is done by combining knowledge from the former step (hermeneutic) and the latter. A synchronic ${ }^{3}$ interpretation is needed since the texts are from ancient times while the experiences of the phenomenon are more recent. Concisely, the research methods are shown in Figure 2. The understanding of accounting in the Javanese Slametan would also bring understanding of the underlying values.

\section{Results and Discussion}

Firstly This part of the article explains the two positioning stands of this research: accounting and the Javanese culture. It is imperative to match the readers' perception with this article's delineation. First, accounting terminology view is taken, then the explanation moves on to Javanese communal religious feasts or ceremonies that reflect the presence of accounting in socio-economic activities.

\subsection{Defining Accounting}

In many socio-economic activities there are always some forms of accounting. However, it is necessary to elucidate the term accounting in this writing (read: in the Javanese culture).

Accounting is an art or a service activity and indirectly state that accounting consists of a group of techniques claimed beneficial for certain areas, but in practice it should obey a framework accepted by accounting profession [12]. Accounting is also an information system [13]. Early definition of accounting by American Institute of Certified Public Accountant (AICPA), stated in 1953, defined accounting as the art of recording, classifying and summarizing in a significant manner and in terms of money, transactions and events which are, in part at least, of a financial character, and interpreting the results thereof (Hamm, 2002). In 1970 AICPA added

\footnotetext{
${ }^{3}$ An approach to a phenomenon analysis on cut-off periods, rather than historical developments (Pilliang, 2003: 27)
} 
to this definition with "...to provide quantitative information, primarily financial in nature, about economic entities that is intended to be useful in making economic decisions."

There are several definitions of accounting sprung from several theories of accounting with different paradigms, and we believe this revolution is not coming to a stop. As accounting has evolved, accountants have gradually adopted more global points of view in both theory construction and problem solving. One of the problems associated with extending the bounds of accounting thought, however is the emergence of divergent terminology [14].

Therefore, referring to Silhan, it would be permissible to take the liberty to settle on the early definition of accounting which states that it is an art of, or a service activity and indirectly states that accounting consists of a group of techniques claimed beneficial for certain areas. Belkaoui [12] stated that it should follow a certain framework. This paper views this framework as a culture, a traditional form, not the conventional one.

Thus by that definition of accounting as mere art or service activities with groups of techniques, this article would remain onward. Though not clearly stated such definition was employed by Jacobs and Kemp [15] while exploring accounting presence and absence in Bangladesh. They claimed that there was a presence of accounting in three traders in Bangladesh by observing as simple as that there was entry to account book, "an elongated, battered book filled with names and lists of figures that have mostly been crossed out as settlements have been made" [15]

\subsection{Accounting in Javanese Culture and its Religious Aspect}

So what framework would fit accounting in the Javanese culture? The answer lies on the culture itself. Culture as described by Soemardjan [16] can be viewed in three perspectives. First, as products of peoples' thought which generate theories, languages, ideologies that are abstract. Second, as products of feeling that generate arts, values and ethics. Third, as products of works that generate objects which can be seen, touched and held. However, Soemardjan did not emphasize that the three prespective could very much overlap.

We live in a culture that is often taken for granted (always there and understood as something that it is what it should be). Culture, thus, can be defined simply by environment we live in with all its cultural objects (technology), cultural behavior, and cultural values held. Values transferred, mainly from parents and environment, are hardly questioned for they are believed as something proper. It has merged in unconsciousness and become a habitus ${ }^{4}$. These values include religious beliefs.

The reason why it is important to discuss religion in culture is because it is inevitable to discuss Javanese culture without probing into its religious beliefs. Religions have become the center of daily life and religious leaders have placed themselves highly in the society. As Kuntowijoyo [17] claimed that in Javanese villages the role of kyai exceeds his role as Islam religious leader.

However, there is a unique characteristic of Islam in Java for one reason. Java has absorbed several beliefs: Hindu, Budha, and Islam. Initially, the teaching of Hindu and Budha offered a great opportunity for the augmentation of animism, magic, mysticism, spirit and places worshipping. As Islam invaded Java, being an egalitarian religion, the religion quickly spread through. On the other hand, aristocratic and hierarchial structure of Javanese made it possible for these older beliefs to survive, while receiving Islam simultaneously. The result is a civilization called kejawen/ kejawaan/ Javanism [18].

Thus in this paper, the Javanese culture being portrayed is the practice of kejawen ritual, which can still be found nowadays, carried through from generation to generation and this is Slametan. Slametan shows desires to reach a "slamet" condition in a chaotic world. This is a condition when all events follow a destined path smoothly without any unfortunate events experienced by anyone [18]. The Slametan is clearly a community ritual. Newberry [19] refers this as a structure of feeling. The Slametan is still a local, neighborhood ritual staged in a house. Thus, patterns of

\footnotetext{
${ }^{4}$ Bourdieu concept of habitus implies a conceptual and empirical construct that contains and reflects the "politics" that influence agents' interpretations of and manner on acting on the social world [21].
} 
invitation and labor exchange were longstanding and tended to reproduce sets of relationships that endured for some time. It is possible that this structure of feelings is what that has kept Slametan alive.

Geertz [9] describes that it is hard to estimate the cost of giving slametans "not only because people do not keep records of such expenditures but also because figures giving amounts of money in a foreign currency are often quite meaningless or misleading even if one knows the exchange rate." This does not mean that there is no accounting found in the cultural ceremonies for three reasons.

First, during 1953-1959 the literary rate was low, thus as found in the case of Bangladesh studied by Jacobs and Kemp [15], there was a tight correlation between literary rate and the presence of accounting. Not recording any notes at that time was considered normal since there was no ability to read or write, but that did not mean people forgot.

Second, the term of money as notes or recordings limit accounting in the Javanese culture. Thus, accounting may extend to intangible recordings that may reflect rukun (closeness to neighbors) and transcendental beliefs. Geertz [9] himself stated that in slametan there is a sense of reciprocity as shown in one of his ethnographic notes: "if she (the informant) were obligated to give a buwuh, she would do so whether she attended the celebration or not... the wife of Abdullah (the one who was having slametan) gave her a buwuh when she is had a baby so she must go and give buwuh in return". This reflects that slametan involves social obligation though unwritten.

Third, the term of money as notes or recordings limit accounting in Javanese culture. If assets in conventional accounting can be simply measured by monetary units, this will not be the case in the Javanese culture. Contribution in slametan varies greatly: from labor (neighbors and relatives came to help out in preparing food) to buwuh as actual food used at the feast and money. Geertz, however, succeeded in achieving monetary figures for some of the cost of slametan as shown in figure 2, though it lacks social respects immeasurable in monetary terms.

Figure 1. The cost of Slametan (1953-1959)

\begin{tabular}{|l|l|}
\hline 4. Type of Slametan & $\begin{array}{l}\text { Cost } \\
(\mathbf{R p})\end{array}$ \\
\hline $\begin{array}{l}\text { "Dream" slametan (urban laborer, as it was the end of the month, no rice } \\
\text { included) }\end{array}$ & 3 \\
\hline Megengan (policemen) & 5 \\
\hline Name changing & 15 \\
\hline Pasaran for babies (policemen) & 20 \\
\hline Moving & 30 \\
\hline Maleman & 40 \\
\hline Wedding (urban laborer) & 600 \\
\hline
\end{tabular}

Source: Geertz, 1976 p. 36.

\subsection{Philosophical values: Evidence from Serat and Other Forms of Texts.}

Interpretation of Javanese Serat that reflects the period before and after the arrival of Islam in 1426 could be analyzed through hermeneutic as method of research to extract values that become the foundations of these beliefs. Javanese serat is full of rhetoric. Rhetoric is an art of expression and persuasion. Rhetoric must be studied through philosophical and ideological connotation as a phenomenon, which does not just adorn meanings but also shapes meanings. It is not just a poetical trick or fiction or poem, but it is a sign [20]. The reason behind this study is to understand why accounting in Slametan, which is proven by the presence of simple bookkeeping as illustrated in appendix 1 , survives up to this day.

The findings suggest that the underlying value that could be extracted is spirituality. Spirituality is present in most Serat, even before approximately 300 years before the entrance of Islam. Kakawin (1032) implies that God is the mover of the world (see appendix 1, p i) that is also regarded as The Highest Knowledge. It is possible to reach God if one could free oneself from will, 
or as the Serat states "limpad sakêng śünyatā" or leap from emptiness, which is the emptiness of egoistic will.

In 1823-1830, after the entrance of Islam Serat Pupuh Maskumambang still puts emphasis on God through "kudu musthi awas eling, marang kodrating Hyang Suksma". The use of "Hyang Suksma" indicates the residual influence of Hinduism in Javanese spirituality. Javanese spirituality is also tightly correlated with knowledge, and acquiring knowledge must be put into the sake of others' well being. These altruistic intentions lead to actions as pictured by Wedhatama, Pocung, written approximately in 1809-1881. "Ngelmu" or knowledge must be put in use for goodness or "nyantosani".

Actions or deeds of a Javanese are governed by spirituality: "Narima ing Pandum" (shows complete surrender to destiny), "Aja kalah karo tangine pitik" (shows diligence at work), and "Mangan ora mangan waton kumpul" (shows the spirit of togetherness through all difficulties) (see appendix 1, p iii) are proverbs that still exist and believed up to this day. Every deed would bring consequence such that is shown by a saying by Ranggawarsita (1803-1873): "Nistha Papa,

Dora Sangsara, Dhusta Lara, Nihaya Pati”. Therefore, one must be very careful of one's action. The concept of wealth is present in the Pupuh Maskumambang, though it is placed at the third from the most important things that are considered fortunes in life.

The society of Java is based on patriarchal values as reflected in Serat Wulangputri written approximately between 1801-1881, that states that the ability of women is an eighth of men (see appendix 1, p iv). However, this probably only stresses the role of the men as heads of families, since in Slametan the role of women is more apparent than men for the following reasons.

First, most recordings or "accounting" are done by women. Though there is no written rule about this, our findings suggest that men are not actively concerned on such activities. Second, actions of social obligations that are revealed by buwuh or donations to Slametan are also carried out by women. Men are required to come to give prayer or conduct the actual ritual of Slametan. Third, women play greater part in labor donation in Slametan compared to men. As correctly stated by Newberry [19], female labor is required to stage a slametan of even the smallest and most minimal kind. The slametan does indeed take place either in front of the house or in its main front room, but this cannot take place without all the backdoor labor of women. As seen in appendix 1, $\mathrm{p}$. vi, photograph 1 and 2, women prepared food together for the feast as well as the preparation of Berkat to be brought home by the invitees.

Simple recordings reveal that unlike Geertz's findings [9], donations given as buwuh are recorded. This is a list of names and addresses, to whom the one who is having the Slametan must return the buwuh when the donator is having a Slametan in return. This physical evidence has proven that obligation recordings or "accounting" is present. The need to do so might arise from the spirit of good-deeds and togetherness (rukun) that springs from Javanese spirituality. However, to obtain a better understanding of the values behind the recordings, it is best to extract experience from the actors of Slametan through phenomenology.

\subsection{Interpreting Accounting Experience in Slametan}

There are varieties of recordings from informants that do not seem to be completely similar. However, we will discuss at this section both similarities and differences, and try to abstract essence of experience both noema and noesis, as an eidetic reduction. From the interviews it is revealed that most recordings are conducted by women and sometimes they appoint others that they can trust to do the recordings. Evidence shows that there are two types of recordings found: non-cash such as rice, sugar, dried noodles etc, and cash. These recordings could then be classified into two: ndeleh and buwuh. In most participants it could be found that there are no recordings on expenses.

At a slametan, a neighbor may give rice, sugar, cooking oil etc at certain amount and calls this as ndeleh. This is like a deposit that must be returned by the host of the slametan if this neighbor would have a slametan in the future. This amount is recorded under the classifications stated by both parties. Since it represents a deposit, then when a time comes for this particular neighbor to have a slametan, she would go around asking the others that she has put ndeleh to return exactly the same amount of goods that she has previously deposited at them. When the goods have been returned, then the recordings would be marked with a sign such as cross. 
Buwuh on the other hand are goods or cash that are given at the slametan, unlike ndeleh that is given or asked for before slametan. It is found that buwuh and ndeleh in the form of goods or noncash is well liked since it does not depreciate in value, unlike money, as explained by Tutik (appendix 2, p i):

"Rice, sugar or any other goods will stay the same amounts. $1 \mathrm{~kg}$ of rice last year is the same as $1 \mathrm{~kg}$ of rice today. But with money, Rp 5.000 last year is not the same with Rp 5.000 today. So with money we must return it with appropriate amount"

It seems that profession has some effect on how people record. Siti Aminah records her buwuh according to areas since she is a peddler of clothing who goes around the surrounding villages and is used to recordings receivables from her trade. We do not find similar fashion of recordings from the rest of the participants.

It is interesting that someone who holds the slametan would know most of the names that contribute to the buwuh. Most of participants admit that they could remember one whole kampong residents' names (up to 400-700 names). This again shows strong togetherness in the Javanese society.

However, there is another type of recording that is not physical but mental. It seems that the togetherness amongst the Javanese causes the fact that 'mental' recordings are stronger than physical recordings. These 'mental' recordings are very important since it involves feeling of social obligations, rukun or togetherness, as confirmed by Yani:

"Forgetting to record? No...Usually guests who came late were not recorded but Bapak ${ }^{5}$ would remind me how much they give buwuh...If we were to go for a buwuh, and there was no recording then Bapak would remind me... the most important thing if you go for a buwuh don't give less than what you have received before."

That is why in some physical recordings there are no dates. Tutik, Siti Aminah, Mujiono, Yani confirm this. However, at other slametan Yani has recorded the dates $\left(26^{\text {th }}\right.$ August 2001 and $8^{\text {th }}$ January 2006). This is because dates are not important. It is the obligations that are important, and obligations must be paid sooner or later. When asked about the possibility that some may not pay back, Tutik stated:

"If they do not pay, I would come and ask for it, but this is a rare occasion. I would say to them: I have put ndeleh or buwuh this much. They would be reminded and then give what you ask for. If you do not pay then you would feel bad to your neighbor and yourself...in kampong, we live close like brothers and sisters."

Therefore if these obligations are not paid then there will be embarrassment. Hence, the whole Javanese society is interdependent and cares for one another. Feeling bad whenever one is unable to fulfill his/her obligations is one drive that keeps accounting in slametan alive.

The recent slametan shows that the people have developed accounting system and control for the goods received. These controls include separation of functions. Recordings are done by teenagers, while good-keepings are done by the elderly. This shows that accounting system is based on trust since the elderly is regarded to have better wisdom and is trustworthier. Some 'employ' these functions based on kinship, but the practices are varied across the participants.

Some have even written expenses of slametan, such that is done by Endah. However, it is not the expense or how it has been spent that actually matters, it is the concept of obligation that is strongly present in recordings. Hence, once the expense has been paid, the record is deemed useless. When we asked to see the record of expense, Endah has already lost it:

"The notebook is not kept anymore, since it is no longer important. All that are bought have already been paid. I only keep buwuh records"

Slametan is not just about receiving goods and money. In all participants, there is no intention of gaining material wealth or profit. It serves a higher purpose, that is to gain spiritual satisfaction (show gratitude to God as expressed by Yani; to show that the children are already mentas ${ }^{6}$ as they

\footnotetext{
5 Yani's husband

${ }^{6}$ mentas means that a phase of life has been passed through, and a new life awaits.
} 
get into a new married life), making new friends and relations (as expressed by Siti Aminah and Mujiono).

\subsection{Synchronic Analysis: Accounting in Slametan and its Value}

Interpretations of serat show that there are philosophical values in Javanese culture. These are spirituality and Godliness (Kakawin (1030), Serat Pupuh Maskumambang (1830s)), altruisticism (Wedhatama, 1809), patriarchal values (Serat Wulangputri, 1800s), good deeds versus shameful acts (Ranggawarsita, 1800s) and togetherness (several proverbs).

These values from ancient texts still exist in the present slametan. The phenomenological study has shown that slametan is a reflection of gratitude towards God, hence spiritual in essence. The cohesiveness or togetherness is strongly apparent among the Javanese people. Buwuh or ndeleh shows the spirit of altruicism besides social obligation. When one is having slametan, the rest would help out in labor, goods and cash. It is this togetherness that becomes the value that drives the presence and perseverance of accounting in slametan. The concept of obligation has become an underlying value of all recordings. It is in line with Ranggawarsita's concept that every good deed would be paid accordingly therefore obligation must be settled sooner or later. That is why most of the Javanese slametan records we find in this research have no specific dates found since obligation would stay on unless settled.

As for patriarchal values found in Serat Wulangputri that states the ability of women are an eighth of men, we find no direct evidence of such a thing. The separation of men and women during slametan and that men are placed in the front of the house while the women at the back is a symbol of religious view that states women and men should not mingle in public places, especially if they do not have a permissible relation (mahram). Women play great roles in slametan which include recording buwuh and ndeleh, as well as donating labor to cook or prepare berkat.

Since buwuh and ndeleh must be returned, it seems that goods are well liked compared to cash, since goods do not depreciate in values. This is the spirit of justice in accounting or altruisticism. Recording is thus free from egoistic values such as material gain or profit. It must also be noted that since the concept of obligation is so strong, mental recording serves just as well. The purpose of slametan is expressing gratitude to God and better relations to others. It even seems that accounting system and control have started to developed in the slametan, although it has not gone astray from its philosophical values. These values are not present in the conventional double entry accounting.

\section{Conclusion}

The study shows that the values that are presented in the Javanese texts that go back as far as 1030 AC, which are spirituality and Godliness, altruiticism, good deeds and togetherness, are still apparent in the present slametan. This conclusion is taken after employing hermeneutics and phenomenology and then combines both interpretations through synchronic analysis.

The main factor that underlies accounting in the Javanese slametan is the concept of social obligation derived from strong value of togetherness and religiousity/spirituality. It is these values that actually keep the accounting in Javanese slametan alive. They keep its perseverance. It is imperative to understand that accounting in Javanese slametan includes not just physical but also mental recordings. In this light also, the material profit is not as important as spiritual-soul profit. It is not just about the calculation of buwuh over expenses.

Referring to Silhan [14] that accounting definition may vary across different paradigms, then this study proves that from different point of view, the Javanese accounting in slametan involves values (social obligations, mental recordings, soul-spiritual profit) that are not yet developed in the conventional accounting. It is possible, as this case has shown, that these values are not always accepted (or not yet accepted) by the accounting profession.

The limitation of this study is that it only focuses on two types of slametan: marriage and circumcision. Other types of slametan might yield different results. Further, our informants are from East Java. Other area of Java (West or Middle Java) might also have different views about accounting in slametan. Variations of practices are abundant and these need to be explored. 


\section{References}

[1] Budiono H. Simbolisme Jawa. Yogyakarta: Penerbit Ombak; 2002.

[2] Cooper C, Neu D, Lehman G. Globalization and its Discontents: A Concern about Growth and Globalization. Account Forum 2003;27:359-64. doi:https://doi.org/10.1046/j.1467-6303.2003.00110.x.

[3] Nader R, Wallach L. GATT, NAFTA, and The Subversion of The Democratic Process. The Case Against the Global Economy. 1993.

[4] George S. A Short History of Neoliberalism. Conf. Econ. Sovereignty a .Globalizing World, 1999, p. 24-6.

[5] Abeysekara I. International Harmonisation of Accounting Imperialism- An Australian Perspective. Crit. Manag. Stud. Conf., Canada: 2005.

[6] Lehman G. A critical perspective on the harmonisation of accounting in a globalising world. Crit Perspect Account 2005;16:975-92. doi:10.1016/j.cpa.2003.06.004.

[7] Weber M. The Protestant Ethic and the Spirit of Capitalism. The Protestant Ethic, 1930. doi:10.1007/978-3-658-07432-6.

[8] Suyono CRP. Dunia Mistik Orang Jawa. Yogyakarta: PT LKIS Pelangi Aksara Yogyakarta; 2007.

[9] Geertz C. The Religion of Java. USA: The University of Chicago Press.; 1976.

[10] Burrell, Morgan. Sociological Paradigms and Organisational Analysis: Elements of the Sociology of Corporate Life. England: Arena; 2005.

[11] Sanders P. Phenomenology: A New Way of Viewing Organizational Research. Acad Manag Rev 2011. doi:10.5465/amr.1982.4285315.

[12] Belkaoui AR. Accounting Theory. Chicago: Cengage Learning EMEA; 2004.

[13] Keiso DE, Weygandt JJ. Akuntansi Intermediate. Jilid 1. Jakarta: PT. Binarupa Aksara; 1995.

[14] Silhan PA. The Recurring Problem of Divergent Terminology. Account Rev 1978.

[15] Jacobs K, Kemp J. Exploring accounting presence and absence: Case studies from Bangladesh. Accounting, Audit Account J 2002. doi:10.1108/09513570210425592.

[16] Soemardjan S. Otonomi Daerah: Pendalaman Ekonomi Rakyat 2002.

[17] Kuntowijoyo. Paradigma Islam: Interpretasi untuk Aksi. Bandung: Mizan; 1999.

[18] Mulder N. Mistisisme Jawa: Ideologi di Indonesia. Yogyakarta: PT LKIS Pelangi Aksara Yogyakarta; 2007.

[19] Newberry J. Rituals of Rule in the Administered Community: The Javanese Slametan Reconsidered. Mod Asian Stud Cambridge Univ Press 2007;41:1295-329. doi:https://doi.org/10.1017/s0026749x06002575.

[20] Cavallaro D. Critical and Cultural Theory: Teori Kritis dan Budaya. Translation. Yogyakarta: Futuh Printika; 2001. 
[21] Shenkin M, Coulson AB. Accountability through activism: Learning from Bourdieu. Accounting, Audit Account J 2007. doi:10.1108/09513570710741037. 